\title{
MP
}

\section{Efficient use of artificial micro-RNA to downregulate the expression of genes at the post-transcriptional level in Arabidopsis thaliana}

\author{
A. Ud-Din ${ }^{1,4}$, M. Rauf ${ }^{4}$, S. Ghafoor ${ }^{1}$, M.N.K. Khattak ${ }^{2}$, M.W. Hameed ${ }^{3}$, H. Shah ${ }^{5}$, \\ S. Jan ${ }^{1}$, K. Muhammad ${ }^{1}$, A. Rehman ${ }^{2}$ and Inamullah ${ }^{1}$ \\ ${ }^{1}$ Department of Genetics, Garden Campus, Hazara University, Mansehra, Pakistan \\ 2Department of Zoology, Garden Campus, Hazara University, Mansehra, Pakistan \\ ${ }^{3}$ Dr. Panjwani Center for Molecular Medicine and Drug Research, \\ University of Karachi, Karachi, Pakistan \\ ${ }^{4}$ Institute of Biochemistry and Biology, University of Potsdam, Potsdam, Germany \\ ${ }^{5}$ National Agricultural Research Centre, Islamabad, Pakistan \\ Corresponding author: A. Ud-Din \\ E-mail: azizkhan91@yahoo.com / azizkhan@hu.edu.pk
}

Genet. Mol. Res. 15 (2): gmr.15027439

Received August 13, 2015

Accepted December 7, 2015

Published April 7, 2016

DOI http://dx.doi.org/10.4238/gmr.15027439

\begin{abstract}
Micro-RNAs are cellular components regulating gene expression at the post-transcription level. In the present study, artificial micro-RNAs were used to decrease the transcript level of two genes, AtExpA8 (encoding an expansin) and AHL25 (encoding an AT-hook motif nuclear localized protein) in Arabidopsis thaliana. The backbone of the Arabidopsis endogenous MIR319a micro-RNA was used in a site-directed mutagenesis approach for the generation of artificial micro-RNAs targeting two genes. The recombinant cassettes were expressed under the control of the CaMV 35 S promoter in individual $A$. thaliana plants. Transgenic lines of the third generation were tested by isolating total RNA and by subsequent cDNA synthesis using oligo-dT18 primers and mRNAs as templates. The
\end{abstract}


expression of the two target genes was checked through quantitative realtime polymerase chain reaction to confirm reduced transcript levels for AtExpA8 and AHL25. Downregulation of AtExpA8 resulted in the formation of short hypocotyls compared with those of the wild-type control in response to low $\mathrm{pH}$ and high salt concentration. This technology could be used to prevent the expression of exogenous and invading genes posing a threat to the normal cellular physiology of the host plant.

Key words: Artificial micro-RNA; Arabidopsis thaliana; qRT-PCR; AtExpA8; AHL25

\section{INTRODUCTION}

Gene expression can be affected by two classes of small RNAs in animals and plants: small interfering RNA and micro-RNA (miRNA). Normal gene function can be interfered on several pre- and post-transcriptional levels by these small RNAs. To inhibit the translation of messenger RNA (mRNA) into a functional protein, cells use protein machinery called RNA-induced silencing complex (RISC). RISC uses small RNAs to recognize and target a very specific complementary motif in the nucleic acids (Bartel, 2004; Filipowicz, 2005). miRNAs are widely distributed, usually 18 to 25 nucleotides noncoding small RNAs. They play important roles in plant development and responses to different kinds of biotic and abiotic stresses by regulating gene expression (LagosQuintana et al., 2003; Bartel, 2004). A number of putative miRNAs have been predicted with the help of high throughput sequencing and computational biology (Sunkar and Jagadeeswaran, 2008; Chandrasekaran et al., 2013). Recently, in animals and plants, endogenous miRNA precursors have been used to develop artificial miRNA technology. This has led to the generation of targetspecific miRNA for gene silencing (Schwab et al., 2006; Molnar et al., 2009; Zhou et al., 2013).

Plant cells secrete different types of proteins and many other enzymes that modify cellulose and other polysaccharides in the cell wall (Fry, 1995). One of these proteins is expressed by expansins, which trigger changes in the cell wall by loosening it (Cosgrove, 2000). Expansins are involved in many processes, mainly in the modification of cell walls including wall dissolution, pollen-tube invasion, cell separation, and control of plant cell growth (Rose and Bennett, 1999; Lee et al., 2001; Cosgrove et al., 2002; Li et al., 2003). Expansin-mediated cell wall enlargement is required for the complex and highly coordinated pattern of growth and morphogenesis in plants.

The differences in the patterns of EXPANSIN expression have different effects on plant morphology, e.g., the expansion of Arabidopsis leaves (Cho and Cosgrove, 2000), soybean roots (Lee et al., 2003), rice internodes (Choi et al., 2003), and wheat coleoptiles (Zhao et al., 2011). Similarly, AT-hook nuclear localized (AHL) proteins also play important roles in plant development (Lim et al., 2007; Xiao et al., 2009). They are widely distributed in a range of plant species namely, Arabidopsis (A. thaliana), rice (Oryza sativa), poplar (Populus trichocarpa), pea (Pisum sativum), Madagascar periwinkle (Catharanthus roseus), maize (Zea mays), and grape vine (Vitis vinifera). About $29 \mathrm{AHL}$ proteins have been identified in A. thaliana (Fujimoto et al., 2004; Grasser et al., 2007; Vom Endt et al., 2007), and are expressed in most plant organs (Matsushita et al., 2007; Street et al., 2008).

In the present study, we successfully downregulated AtExpA8 and AHL25expression using artificial miRNA (amiRNA) to target these genes in individual $A$. thaliana plants and analyzed the effect of down regulated transcript levels on the growth of etiolated hypocotyls in response to low $\mathrm{pH}$ and high salt concentrations compared with that of the wild-type control. The reduction in the 
expression level was determined by quantitative real-time polymerase chain reaction (qRT-PCR). The resulted lines of amiRNA for AtExpA8 were sensitive to stresses such a slow $\mathrm{pH}$ and high salt concentrations as compared with the wild-type control.

The objective of the present study was to downregulate gene expression, i.e., $A H L 25$ and AtExpA8 and investigate their effect on the phenotype of $A$. thaliana transgenic lines.

\section{MATERIAL AND METHODS}

\section{General strategy}

Standard methods such as plasmid isolation, restriction analysis of nucleic acids, gel electrophoresis, cloning and transformations, were performed as described by Hanahan (1983) and Sambrook and Russell (2001).

The oligonucleotides (primers) were synthesized by Eurofins MWG Operon (Ebersberg, Germany). Sequences of the primers used in this study for qRT-PCR were designed using online tool of QuantPrime (Arvidsson et al., 2008).

The primers used to generate the amiRNA constructs fromAtEXPA8 and AHL25 are as follows: A8-miR-s, 5'-GATCTAAGCTAATTAAGCGGGTCTCTCTCTTTTGTATTC-3'; A8-miR-a, 5'-GAGACCCGCTTAATTAGCTTAGATCAAAGAGAATCAATGA-3'; A8-miR*'s, 5'-GAGAACCGCTT AATTTGCTTAGTTCACAGGTCGTGATATG-3'; A8-miR*a, 5'-GAACTAAGCAAATTAAGCGGTTCT CTACATATATATTCCT-3'; and miRAHL-s, 5'-GATCTAGTTATAATCGTCGGACGTCTCTCTTTTGT ATTCC-3'; miAHLR-a, 5'-GACGTCCGACGATTATAACTAGATCAAAGAGAATCAATGA-3'; miRAHL*s, 5'-GACGCCCGACGATTAAAACTAGTTCACAGGTCGTGATATG-3'; miRAHL*a, 5'-GAACTAGTTTTAATCGTCGGGCGTCTACATATATATTCCT-3', with asterisks indicating adapted as described by Schwab et al. (2006).

\section{Plant material and growth conditions}

A. thaliana (L.) Heynh. ecotype Col-0 was used in these experiments. Seeds were surface sterilized with a sterilization solution ( $1 \%$ sodium hypochlorite, $0.02 \%$ Triton $X-100$ ), first treated with $500 \mu \mathrm{L} 70 \%$ ethanol for $5 \mathrm{~min}$ and then $500 \mu \mathrm{L}$ sterilization solution was added in $2-\mathrm{mL}$ Eppendorf tubes and subjected to continuous shaking for $10 \mathrm{~min}$. Subsequently, they were washed three times with sterile distilled water and dried on Whatman filter paper. All steps were performed under sterile conditions in a flow-hood clean bench. Sterile seeds were plated on MS medium with $2 \%$ sucrose and $0.7 \%$ agar (Murashige and Skoog, 1962). The MS medium was supplemented with appropriate selection markers for the selection of positive transformants. Seeds were then exposed to vernalization ( $16 \mathrm{~h}$ light at $140-285 \mu \mathrm{E}, 22^{\circ} \mathrm{C} ; 8 \mathrm{~h}$ dark; $8^{\circ} \mathrm{C}, 70 \%$ humidity) conditions for 1 week and then placed in Percival growth chambers ( $16 \mathrm{~h}$ light at $140-285 \mu \mathrm{E}, 22^{\circ} \mathrm{C} ; 8 \mathrm{~h}$ dark, $22^{\circ} \mathrm{C}, 70 \%$ humidity). The plants were later transplanted to soil (type GS90; Gebr. Patzer, SinntalJossa) in 6-cm pots and maintained in a phytotron growth chamber (16 h light at $80-120 \mu \mathrm{E}, 20^{\circ} \mathrm{C}$; $8 \mathrm{~h}$ dark, $16^{\circ} \mathrm{C} ; 70 \%$ humidity).

\section{Isolation of total RNA}

Total RNA was extracted using either TRIzol Reagent (Gibco Life Technologies; Eggenstein, Germany) or Qiagen RNeasy Plant Mini Kit (Qiagen Hilden, Germany) following manufacturer 
instructions. The fresh or frozen plant material (50-200 mg) was ground in liquid nitrogen and subsequently treated according to the protocol described by the manufacturer. The RNA pellet was dissolved in $30 \mu \mathrm{L}$ RNase-free water for TRIzol, or 25-30 $\mu \mathrm{L}$ elution buffer for Qiagen RNeasy.

\section{First-strand cDNA synthesis and RT-PCR}

First-stand cDNA was synthesized from freshly isolated RNA by reverse transcriptase using Fermentas First strand cDNA synthesis kit (Fermentas, St. Leon-Rot, Germany) according to the manufacturer protocol.

\section{qRT-PCR}

After synthesis of cDNA, it was used to analyze the relevant abundance of a particular mRNA. Efficiency of cDNA synthesized was controlled by qRT-PCR amplification of housekeeping genes UBIQUITIN10 (At4g05320) and ACTIN2 (At3G18780). An ABI PRISM 7300 sequence detection system (Applied Biosystems Applera, Darmstadt, Germany) was used for the amplification and detection of PCR fragments as described by Caldana et al. (2007). The reactions were performed in triplicate and the SDS 2.2.1 software (Applied Biosystems Applera) was used to determine the abundance of each transcript in the respective samples. $C_{T}$ (threshold cycle) values were obtained by analysis of amplification curves with a normalized reporter $\left(R_{n}\right.$ : the ratio of the fluorescence emission intensity of SYBR Green to the fluorescence signal of the passive reference dye) threshold of 0.2 . The obtained data were normalized to the reference gene UBIQUITIN10; $\triangle \mathrm{C}_{\mathrm{T}}$ $=\mathrm{C}_{\mathrm{T}}$ (gene under consideration) $-\mathrm{C}_{\mathrm{T}}$ (UBQ10). The expressions were measured in three replicates in a single PCR run, average $C_{T}$ was used for relative expression analyses.

\section{Measurement of hypocotyl length}

Seeds were germinated on agar containing MS medium plates. Plates were maintained in dark for 3-5 days at $4^{\circ} \mathrm{C}$ to synchronize seed germination and then placed for 1 day in the dark before being exposed to normal growth conditions. Hypocotyl length was measured 3-5 days after germination using the Leica software and a stereomicroscope.

\section{Statistical analysis}

Data were first recorded and then analyzed. Statistical analysis was performed using a $t$-test. Statistically significant differences were confirmed at 0.05 or 0.01 .

\section{RESULTS}

\section{Selected genes for artificial miRNA}

Two genes were selected for the generation of amiRNA constructs: AtExpA8 (At2g40610) and AHL25 (At4g35390). The coding sequence of AtExpA8 comprised of 762 bp encoding a protein of 253 amino acids (Figure 1A). The predicted molecular weight of AtExpA8 is $27.27 \mathrm{kDa}$. The first 25 amino acids are annotated as signal peptides. There are two conserved characteristic domains present in AtExpA8 that classify it as a member of the expansin family. The first domain 
is 103 amino acids long (amino acids 48-160), while the second domain includes 81 amino acids (positions 170-250). The $\mathrm{N}$-terminal domain 1 has structural and sequence similarity to family-45 endoglucanases (EG45-like domain). This domain has a distant homology to the catalytic domain of glycoside hydrolase family $45(\mathrm{GH} 45)$ proteins. Fungal $\beta$-1,4-D-endoglucanases represent most members of this family; members from this family have been characterized and their mechanism of action has been determined (Davies et al., 1995). The C-terminal domain 2 is designated as a putative polysaccharide-binding domain (PP-BD).

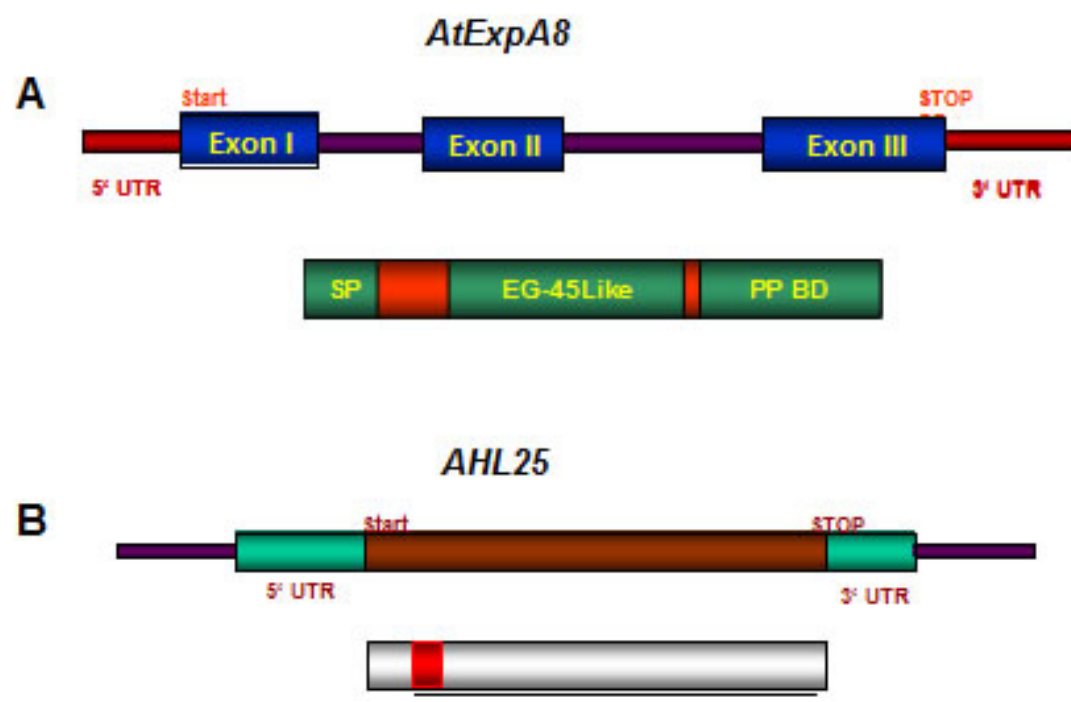

Figure 1. Schematic diagram of the AtExpA8 and AHL25 genes and proteins. A. Pictorial representation of the AtExpA8 gene (A upper) and the protein $27.27 \mathrm{kD}$ (A lower). The SP (amino acids 1-25, signal peptide), conserved EG45-like domain (amino acids 48-160 with structural and sequence similarity to family-45 endoglucanases), and the PP-BD (amino acids 170-250, putative polysaccharide binding domain) are shown. B. Pictorial representation of the AHL25 gene. Start and stop codons, as well as untranslated regions (5'UTR and 3'UTR) are indicated (B upper). The conserved AT-hook motif in the protein is shown in red. The PPC (plants and prokaryotes conserved) domain is underlined (B lower).

The coding sequence of the AT-hook motif protein AHL25 (At4g35390) comprised 897 bp encoding a protein of 299 amino acids (Figure 1B). The predicted molecular weight of AHL25 is $30.5 \mathrm{kDa}$. AHL25 is an intron-less gene. The 5' untranslated region (UTR) and 3'UTR of AHL25 are 277 and $190 \mathrm{bp}$ long, respectively. A number of homologs of $A H L 25$ were also found in other plant species such as Z. mays, O. sativa, V. vinifera, Ricinus communis, and P. trichocarpa (http:// blast.ncbi.nlm.nih.gov).

\section{Generation of artificial miRNA lines}

One of the factors in the functional analysis of a gene is knockout, i.e., to completely diminish or reduce its expression. Therefore, to downregulate AtExpA8 and AHL25 expression, the artificial miRNA method was adopted. Primers were generated using an online tool (http:// wmd.weigelworld.org/cgi-bin/mirnatools.pl). Sequences of the primers used for amplification and generation of the amiAtExpA8 and amiAHL25 are provided in the Material and Methods section. 
The amiRNA for AtExpA8 and AHL25 were generated by overlapping PCR. In the first round of PCR, fragments (a) to (c) were separately amplified using plasmid pRS300 as a template (Schwab et al., 2006). In the fourth round, the amplified fragment was obtained by overlapping PCR (Table 1), where the products of the previous PCRs were used as templates.

The amplified fragments were digested with Xhol and Spel and subsequently cloned individually in a binary vector pJFH1 under the control of the CaMV 35S promoter. A total of 9 and 7 transgenic lines were selected for AtExpA8 and $A H L 25$, respectively, through Agrobacterium tumefaciens transformation and by subsequent selection on kanamycin supplemented media (Figure 2).

\section{Table 1. Scheme of PCRs}

\begin{tabular}{c|c|c}
\hline & Primer pair & Template \\
\hline (a) & A and IV & pRS300 \\
\hline (b) & III and II & pRS300 \\
\hline (c) & I and B & pRS300 \\
\hline (d) & A and B & (a)+(b)+(c) \\
\hline
\end{tabular}

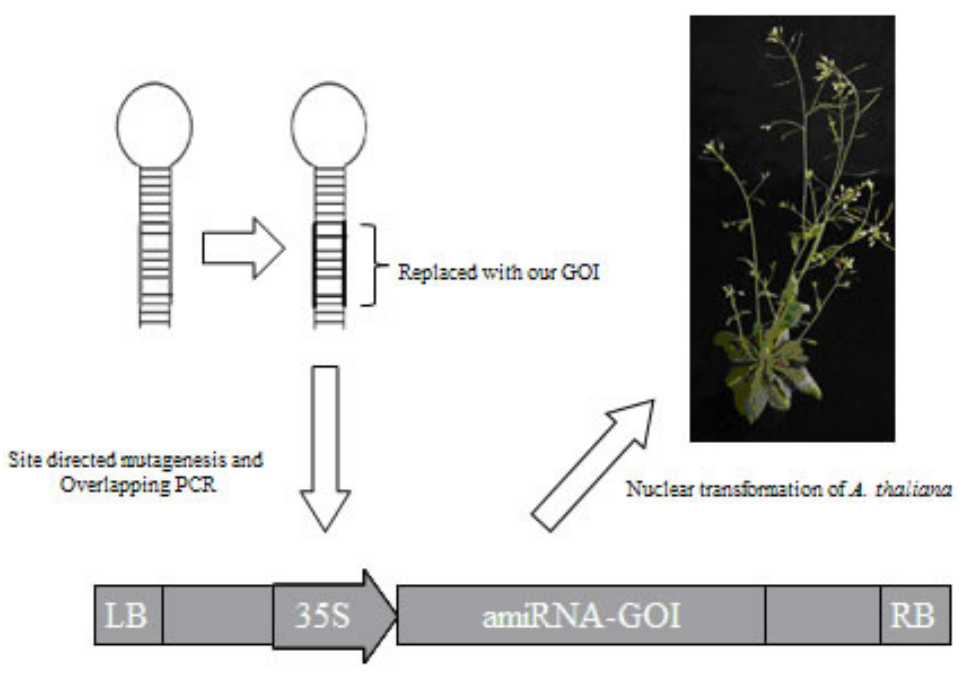

Figure 2. Schematic diagram of artificial miRNA generation. Arabidopsis micro-RNA MIR319a was used as a precursor for the construction of artificial micro-RNA for the gene of interest (GOI) through site-directed PCR followed by overlapping PCR (Schwab et al., 2006). The amplified fragment was cloned under CaMV 35S promoter in a binary vector. Arabidopsis thaliana (Col-0) plants were transformed with the cassette through Agrobacterium tumefaciensmediated nuclear transformation. Third generation (T3) transformed lines were used for further experiments.

\section{Analysis of transcript level through qRT-PCR}

The reduction in the transcript level by artificial miRNA was investigated through qRT-PCR in pamiRNA::ExpA8and pamiRNA::AHL25 lines respectively (Figures 3 and 4). Primers used for qRT-PCR were 5'-ACATCTCTCTGTTTTGGGTGCT-3' and 5'-CAACCATTGAAGCAATAATTCG-3' for AtExpA8 and 5'-GGCTCTTCCTCCGGACGTCG-3' and 5'-GAGACTGCCTCGGATATGTCC-3' for $A H L 25$. 


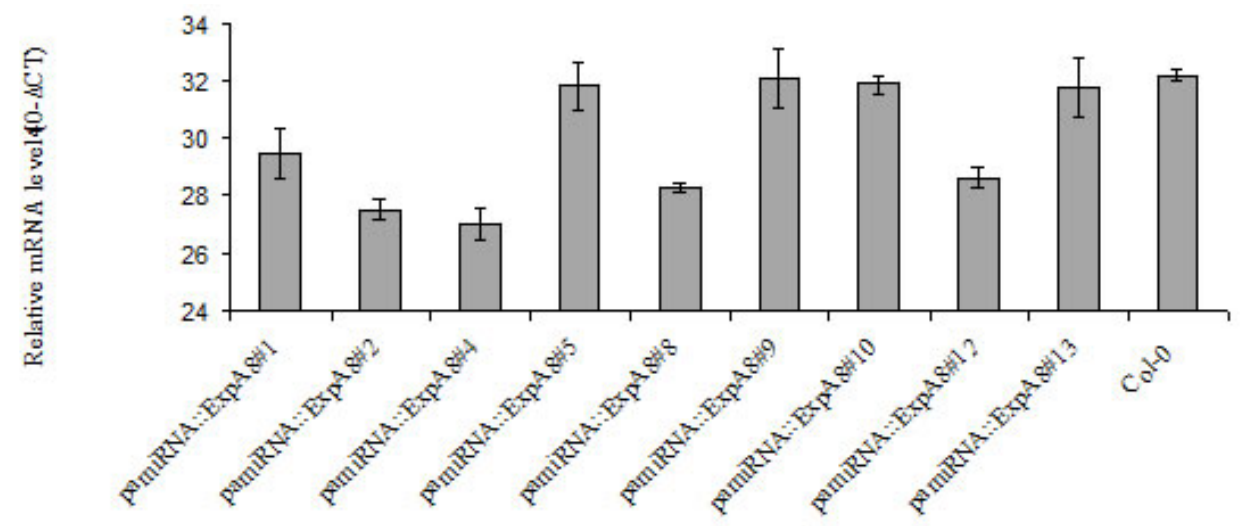

Figure 3. Expression analysis of AtExpA8 in artificial micro-RNA lines in Arabidopsis thaliana Col-0 background. Expression level of AtExpA8 was analyzed through qRT-PCR and normalized to the expression of UBQ10 in different pamiRNA::AtExpA8 transgenic lines (ami\#) and compared with the wild-type (Co-0). Total RNA was extracted and cDNA was made from two week-old seedlings. The mean value of the expression level is given from three technical replicates while error bars indicate the standard deviation.

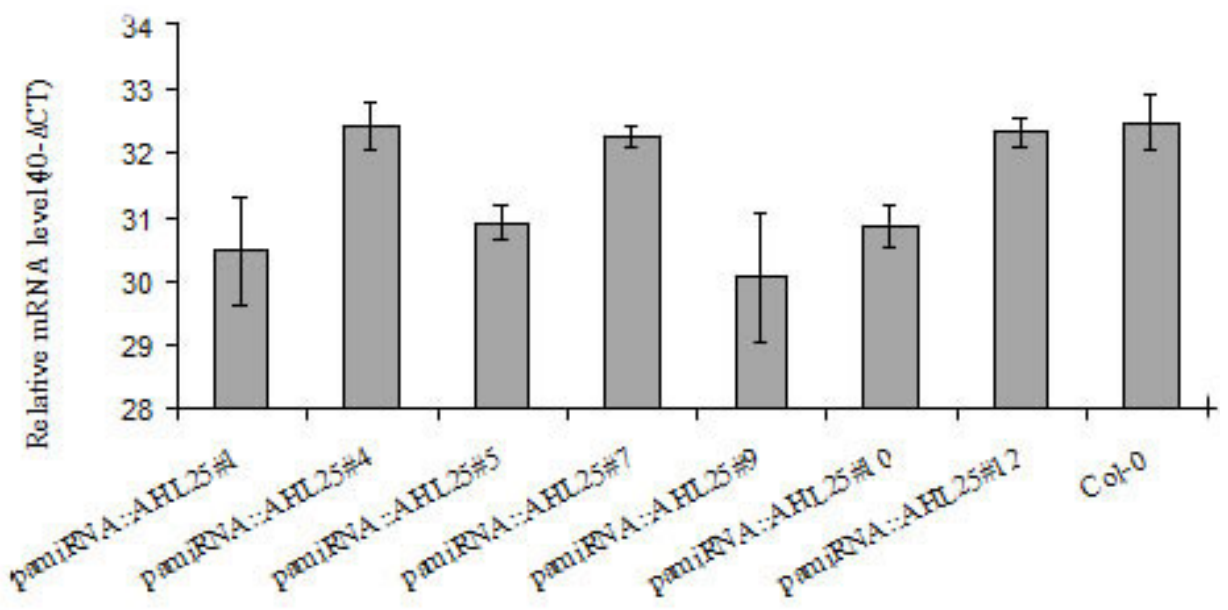

Figure 4. Expression analysis of AHL25 in artificial micro-RNA lines in Arabidopsis thaliana Col-0 background. Expression level of $A H L 25$ was analyzed through qRT-PCR and normalized to the expression of UBQ10 in different pamiRNA::AHL25 transgenic lines and compared with the wild-type (Co-0). Total RNA was extracted and cDNA was made from two-week-old seedlings. The mean value of the expression level is given from three technical replicates while standard deviation is displayed by error bars.

Analysis of the qRT-PCR data showed that AtExpA8 expression was reduced in five lines (pamiRNA::ExpA8\#1, pamiRNA::ExpA8\#2, pamiRNA::ExpA8\#4, pamiRNA::ExpA8\#8, and pamiRNA::ExpA8\#12), while there was no significant reduction in AtExpA8 transcript abundance in pamiRNA::ExpA8\#5, pamiRNA::ExpA8\#9, pamiRNA::ExpA8\#10, and pamiRNA::ExpA8\#13.

Similarly, AHL25 expression was reduced in pamiRNA::AHL25\#1, pamiRNA::AHL25\#5, pamiRNA::AHL25\#9, and pamiRNA::AHL25\#10, while there was only slight or no reduction 
in AHL25 transcript abundance in lines pamiRNA::AHL25\#4, pamiRNA::AHL25\#7, and pamiRNA::AHL25\#12. Transgenic lines with reduced transcript levels for AtExpA8 and AHL25 were used for further analysis.

\section{Abiotic stress and phenotypic response of the artificial miRNA lines}

The effect of low $\mathrm{pH}$ and high $\mathrm{NaCl}$ concentration on the growth of AtExpA8 artificial miRNA seedlings compared to Col- 0 as the wild-type control was investigated. We germinated the seeds in darkness for 3 days and measured the final hypocotyl length. The $\mathrm{pH}$ of the MS medium was adjusted to 5 . The results revealed that there was a significant reduction in hypocotyl length in AtExpA8 miRNA seedlings (Figure 5A). Similarly, $\mathrm{NaCl}(150 \mathrm{mM})$ reduced seedling growth, with reduced AtExpA8 expression than the wild-type Col-0 (Figure 5B). The results demonstrated that reduction in transcript levels of AtExpA8 in miRNA lines reduced their tolerance to low $\mathrm{pH}$ and high salt concentration. These results revealed the negative effects of low $\mathrm{pH}$ and high salt concentration in response to reduced AtExpA8 transcript levels in artificial miRNA lines.

A
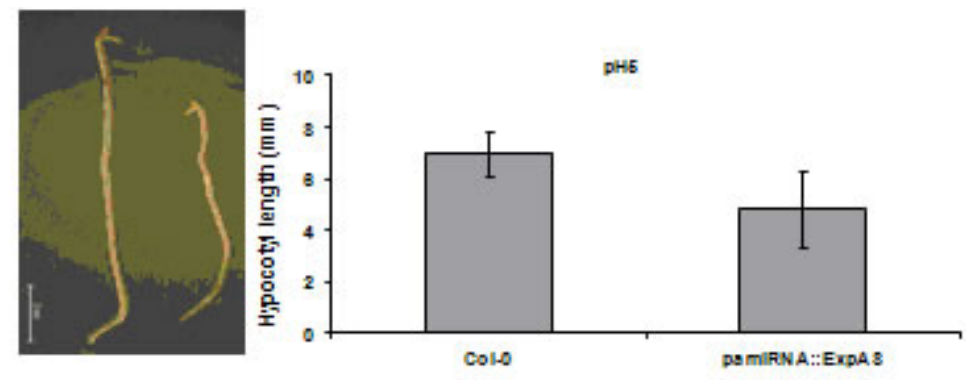

B
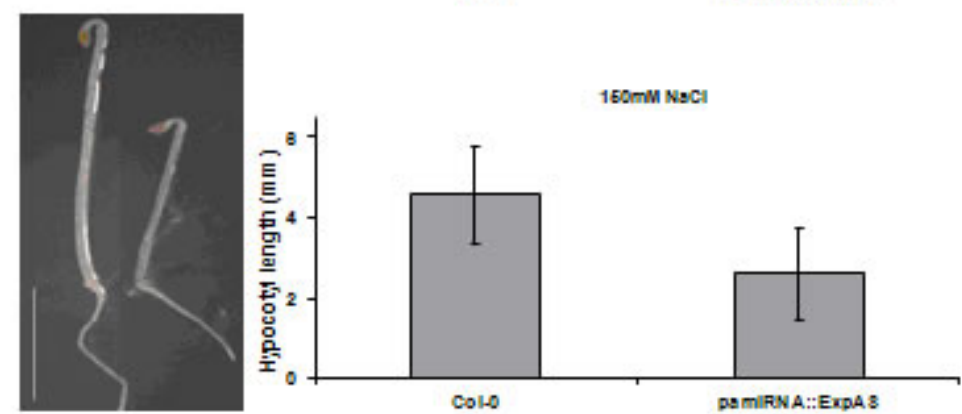

Figure 5. Downregulation of AtExpA8 resulted in high sensitivity to low $\mathrm{pH}$ and high $\mathrm{NaCl}$ concentration. Seeds were germinated on plates containing MS medium with $\mathrm{pH} 5$ (A) or supplemented with $150 \mathrm{mM} \mathrm{NaCl}(\mathbf{B})$. Plants were germinated for 3 days in complete darkness and then the length of hypocotyls was measured. Error bars represent the standard deviation of at least 25 seedlings. Length of hypocotyls is indicated in $\mathrm{mm}$ (y-axis). Scale bars represent $2 \mathrm{~mm}$.

\section{DISCUSSION}

An amiRNA approach was considered particularly important because it can knock down the expression of a gene via RNA interference (RNAi) with high specificity (Schwab et al., 2006). Therefore, we used this technique to downregulate the expression of two genes, i.e., AtExpA8 and AHL25 in A. thaliana. Analysis of the qRT-PCR data showed greater reduced expression of these genes in the 
transgenic plants harboring the amiRNA cassettes than in the control. There were about five individual lines for each of the genes that showed reduced transcript levels indicated in Figures 3 and 4.

The functional role of $A H L 25$ was investigated by its reduced expression in the transgenic lines generated through amiRNA. However, no significant phenotypic differences compared to Col-O were observed in the transgenic lines with reduced mRNA levels for AHL25, although the level of downregulation of $A H L 25$ in some pamiRNA::AHL25 lines was more than $50 \%$ (Figure $5 \mathrm{~B})$. This may be due to the redundancy among the $A H L$ genes, which has also been reported by Xiao et al. (2009), where no phenotypic differences were observed between the wild type and RNAi lines for $A H L 18$ and $A H L 22$.

Cell wall extension is relative to the growth of the tissue and organ, one of the properties of the cell wall is the ability to extend at acidic $\mathrm{pH}$ (Rayle and Cleland, 1992). In the present study, the downregulation of AtExpA8 resulted in more sensitive behavior of the plants towards low $\mathrm{pH}$ and high salt concentration (Figure 5). This indicates the importance of this gene for the normal growth of the plants. This shows that expansin-mediated cell wall enlargement is required for the complex and highly coordinated pattern of growth and morphogenesis in plants.

amiRNAs serve as an effective tool to study the effects of post-transcriptional gene silencing. Previously, naturally occurring antisense transcripts were identified as important regulators of the corresponding sense transcript (Borsani et al., 2005). amiRNAs have an edge over conventional hair-pin mediated RNAi as they are specific in targeting either the sense or antisense RNA. Furthermore, amiRNA can be designed to target a specific splice form of the same gene. Some genes are fundamental for normal growth and development of an organism; hence their loss of function as a knockout mutant is lethal, which makes the use of amiRNA technology an appropriate potential method for determining the downregulation of gene expression and its effect on the studied organism.

Another fundamental aspect of artificial miRNA is that it has been used to downregulate the expression of exogenous genes e.g., the invading virus pathogen in wheat, such as the wheat streak mosaic virus (Fahim et al., 2012).

In conclusion, miRNAs are naturally occurring small RNAs that regulate the expression of genes at the post-transcriptional level; in the present study we used this technology by making amiRNAs against two genes in Arabidopsis. The expression of these genes was successfully downregulated, which was evident from the analysis of the transcript of these genes through qRT-PCR.

\section{Conflicts of Interest}

The authors declare no conflict of interest.

\section{ACKNOWLEDGMENTS}

Research supported by the Higher Education Commission Pakistan (HEC) and the DAAD (Deutscher Akademischer Austauschdienst) Germany.

\section{REFERENCES}

\footnotetext{
Arvidsson S, Kwasniewski M, Riaño-Pachón DM and Mueller-Roeber B (2008). QuantPrime--a flexible tool for reliable highthroughput primer design for quantitative PCR. BMC Bioinformatics 9: 465. http://dx.doi.org/10.1186/1471-2105-9-465

Bartel DP (2004). MicroRNAs: genomics, biogenesis, mechanism, and function. Cell 116: 281-297. http://dx.doi.org/10.1016/ $\underline{\mathrm{S} 0092-8674(04) 00045-5}$
} 
Borsani O, Zhu J, Verslues PE, Sunkar R, et al. (2005). Endogenous siRNAs derived from a pair of natural cis-antisense transcripts regulate salt tolerance in Arabidopsis. Cell 123: 1279-1291. http://dx.doi.org/10.1016/j.cell.2005.11.035

Caldana C, Scheible WR, Mueller-Roeber B and Ruzicic S (2007). A quantitative RT-PCR platform for high-throughput expression profiling of 2500 rice transcription factors. Plant Methods 3: 7. http://dx.doi.org/10.1186/1746-4811-3-7

Chandrasekaran U, Wang X and Liu A (2013). Characterization, expression profiling and heterologous function analysis of two oleosin genes PvOle1 and PvOle2 from Sachalnchi (Plukenetiavolubilis). Int. J. Agric. Biol. 15: 435-442.

Cho HT and Cosgrove DJ (2000). Altered expression of expansin modulates leaf growth and pedicel abscission in Arabidopsis thaliana. Proc. Natl. Acad. Sci. USA 97: 9783-9788. http://dx.doi.org/10.1073/pnas.160276997

Choi D, Lee Y, Cho HT and Kende H (2003). Regulation of expansin gene expression affects growth and development in transgenic rice plants. Plant Cell 15: 1386-1398. http://dx.doi.org/10.1105/tpc.011965

Cosgrove DJ (2000). Loosening of plant cell walls by expansins. Nature 407: 321-326. http://dx.doi.org/10.1038/35030000

Cosgrove DJ, Li LC, Cho HT, Hoffmann-Benning S, et al. (2002). The growing world of expansins. Plant Cell Physiol. 43: 14361444. http://dx.doi.org/10.1093/pcp/pcf180

Davies GJ, Tolley SP, Henrissat B, Hjort C, et al. (1995). Structures of oligosaccharide-bound forms of the endoglucanase $\mathrm{V}$ from Humicola insolens at 1.9 A resolution. Biochemistry 34: 16210-16220. http://dx.doi.org/10.1021/bi00049a037

Fahim M, Millar AA, Wood CC and Larkin PJ (2012). Resistance to Wheat streak mosaic virus generated by expression of an artificial polycistronic microRNA in wheat. Plant Biotechnol. J. 10: 150-163. http://dx.doi.org/10.1111/j.1467$\underline{7652.2011 .00647 . x}$

Filipowicz W (2005). RNAi: the nuts and bolts of the RISC machine. Cell 122: 17-20. http://dx.doi.org/10.1016/j.cell.2005.06.023

Fry SC (1995). Polysaccharide-modifying enzymes in the plant cell wall. Annu. Rev. Plant Physiol. Plant Mol. Biol. 46: $497-520$. http://dx.doi.org/10.1146/annurev.pp.46.060195.002433

Fujimoto S, Matsunaga S, Yonemura M, Uchiyama S, et al. (2004). Identification of a novel plant MAR DNA binding protein localized on chromosomal surfaces. Plant Mol. Biol. 56: 225-239. http://dx.doi.org/10.1007/s11103-004-3249-5

Grasser M, Christensen JM, Peterhänsel C and Grasser KD (2007). Basic and acidic regions flanking the HMG-box domain of maize HMGB1 and HMGB5 modulate the stimulatory effect on the DNA binding of transcription factor Dof2. Biochemistry 46: 6375-6382. http://dx.doi.org/10.1021/bi6024947

Hanahan D (1983). Studies on transformation of Escherichia coli with plasmids. J. Mol. Biol. 166: 557-580. http://dx.doi. org/10.1016/S0022-2836(83)80284-8

Lagos-Quintana M, Rauhut R, Meyer J, Borkhardt A, et al. (2003). New microRNAs from mouse and human. RNA 9: $175-179$. http://dx.doi.org/10.1261/rna.2146903

Lee DK, Ahn JH, Song SK, Choi YD, et al. (2003). Expression of an expansin gene is correlated with root elongation in soybean. Plant Physiol. 131: 985-997. http://dx.doi.org/10.1104/pp.009902

Lee Y, Choi D and Kende H (2001). Expansins: ever-expanding numbers and functions. Curr. Opin. Plant Biol. 4: $527-532$. http://dx.doi.org/10.1016/S1369-5266(00)00211-9

Li Y, Jones L and McQueen-Mason S (2003). Expansins and cell growth. Curr. Opin. Plant Biol. 6: 603-610. http://dx.doi. org/10.1016/j.pbi.2003.09.003

Lim PO, Kim Y, Breeze E, Koo JC, et al. (2007). Overexpression of a chromatin architecture-controlling AT-hook protein extends leaf longevity and increases the post-harvest storage life of plants. Plant J. 52: 1140-1153. http://dx.doi. org/10.1111/j.1365-313X.2007.03317.x

Matsushita A, Furumoto T, Ishida S and Takahashi Y (2007). AGF1, an AT-hook protein, is necessary for the negative feedback of AtGA3ox1 encoding GA 3-oxidase. Plant Physiol. 143: 1152-1162. http://dx.doi.org/10.1104/pp.106.093542

Molnar A, Bassett A, Thuenemann E, Schwach F, et al. (2009). Highly specific gene silencing by artificial microRNAs in the unicellular alga Chlamydomonas reinhardtii. Plant J. 58: 165-174. http://dx.doi.org/10.1111/j.1365-313X.2008.03767.x

Murashige T and Skoog F (1962). A revised medium for rapid growth and bioassays with tobacco tissue cultures. Plant Physiol. 15: 473-497. http://dx.doi.org/10.1111/j.1399-3054.1962.tb08052.x

Rayle DL and Cleland RE (1992). The Acid Growth Theory of auxin-induced cell elongation is alive and well. Plant Physiol. 99: 1271-1274. http://dx.doi.org/10.1104/pp.99.4.1271

Rose JK and Bennett AB (1999). Cooperative disassembly of the cellulose-xyloglucan network of plant cell walls: parallels between cell expansion and fruit ripening. Trends Plant Sci. 4: 176-183. http://dx.doi.org/10.1016/S1360-1385(99)01405-3

Sambrook J and Russell DW (2001). Molecular Cloning: A Laboratory Manual. Cold Spring Harbor Laboratory, Cold Spring Harbor, New York.

Schwab R, Ossowski S, Riester M, Warthmann N, et al. (2006). Highly specific gene silencing by artificial microRNAs in Arabidopsis. Plant Cell 18: 1121-1133. http://dx.doi.org/10.1105/tpc.105.039834

Street IH, Shah PK, Smith AM, Avery N, et al. (2008). The AT-hook-containing proteins SOB3/AHL29 and ESC/AHL27 are negative modulators of hypocotyl growth in Arabidopsis. Plant J. 54: 1-14. http://dx.doi.org/10.1111/j.1365$\underline{313 X .2007 .03393 . x}$ 
Sunkar R and Jagadeeswaran G (2008). In silico identification of conserved microRNAs in large number of diverse plant species. BMC Plant Biol. 8: 37. http://dx.doi.org/10.1186/1471-2229-8-37

Vom Endt D, Soares e Silva M, Kijne JW, Pasquali G, et al. (2007). Identification of a bipartite jasmonate-responsive promoter element in the Catharanthus roseus ORCA3 transcription factor gene that interacts specifically with AT-Hook DNAbinding proteins. Plant Physiol. 144: 1680-1689. http://dx.doi.org/10.1104/pp.107.096115

Xiao C, Chen F, Yu X, Lin C, et al. (2009). Over-expression of an AT-hook gene, AHL22, delays flowering and inhibits the elongation of the hypocotyl in Arabidopsis thaliana. Plant Mol. Biol. 71: 39-50. http://dx.doi.org/10.1007/s11103-0099507-9

Zhao MR, Li F, Fang Y, Gao Q, et al. (2011). Expansin-regulated cell elongation is involved in the drought tolerance in wheat. Protoplasma 248: 313-323. http://dx.doi.org/10.1007/s00709-010-0172-2

Zhou J, Yu F, Chen B, Wang X, et al. (2013). Universal vectors for constructing artificial microRNAs in plants. Biotechnol. Lett. 35: 1127-1133 http://dx.doi.org/10.1007/s10529-013-1197-3. 